\title{
RECORD OF NEW SPECIES OF PARASITOIDS ON LARVAE OF Spodoptera frugiperda (J. E. SMITH) (LEPIDOPTERA: NOCTUIDAE) AND Dichomeris famulata MEYRICK (LEPIDOPTERA: GELECHIIDAE) IN MAIZE (Zea mays L.) IN BRAZIL
}

\author{
RAFAEL BRAGA DA SILVA ${ }^{1}$, IVAN CRUZ², MARIA DE LOURDES CORRÊA FIGUEIREDO ${ }^{3}$, \\ MARCO AURÉLIO BORTONI ${ }^{4}$, ALINE GARCIA PEREIRA ${ }^{1}$, IVY FRIZO DE MELO ${ }^{1}$, \\ LUIZA FIGUEIREDO CAMARGO ${ }^{4}$ and ANGÉLICA MARIA PENTEADO-DIAS ${ }^{5}$
}

\author{
${ }^{1}$ Doutorando (a) em Ecologia e Recursos Naturais, UFSCar, São Carlos, SP, Brasil, rafaelentomologia@yahoo.com.br, \\ alinegpbio@yahoo.com.br,ivyfrizo@yahoo.com.br \\ ${ }_{2}^{2}$ Pesquisador,Embrapa Milho e Sorgo, Sete Lagoas, MG, Brasil,ivancruz@cnpms.embrapa.br \\ ${ }^{3}$ Pós-doutoranda Empresarial CNPq, Embrapa Milho e Sorgo, Sete Lagoas, MG, Brasil, figueiredomlc@yahoo.com.br \\ ${ }^{4}$ Mestrando (a) em Ecologia e Recursos Naturais, UFSCar, São Carlos, SP, Brasil, marcoabortoni@yahoo.com.br, \\ luizafigueiredocamargo@hotmail.com \\ ${ }^{5}$ Professora Titular, UFSCar, São Carlos, SP, Brasil, angelica@ufscar.br
}

Revista Brasileira de Milho e Sorgo, v.11, n.1, p. 115-119, 2012

\begin{abstract}
The knowledge of the flow of parasitoids in cultivation areas is a practice that should be adopted for choosing a best method for the regulation of pest populations. The aim of this study was to determine the occurrence of parasitoids associated with larvae of Spodoptera frugiperda (J. E. Smith) (Lepidoptera: Noctuidae) and Dichomeris famulata Meyrick (Lepidoptera: Gelechiidae) in maize (Zea mays L.) under organic and conventional production system. The experiment was conducted at the National Research Center for Maize and Sorghum (CNPMS) in Sete Lagoas, Minas Gerais State, Brazil. Hymenoptera parasitoids emerged from S. frugiperda, including the Ichneumonidae: Campoletis flavicincta, Colpotrochia sp. nov., Eiphosoma laphygmae and Ophion flavidus; the Braconidae species Chelonus (Chelonus) insularis, Dolichozele koebelei and Exasticolus sp. nov. This is the first report of Colpotrochia sp. nov., Dolichozele koebelei and Exasticolus sp. nov. parasitizing $S$. frugiperda. From larvae of $D$. famulata emerged the Braconidae: Cotesia sp., Glyptapanteles sp., Phanerotoma sp. (Group Fuscovaria) and Chelonus (Microchelonus) sp. nov. (first occurrence in D. famulata).
\end{abstract}

Key words: agroecology, biological control, Braconidae, Ichneumonidae, taxonomy.

\section{REGISTRO DE NOVAS ESPÉCIES DE PARASITOIDES DE LARVAS DE Spodoptera frugiperda (J. E. SMITH) (LEPIDOPTERA: NOCTUIDAE) E Dichomeris famulata MEYRICK (LEPIDOPTERA: GELECHIIDAE) EM MILHO (Zea mays L.) NO BRASIL}

RESUMO - O conhecimento do fluxo de parasitoides em áreas de cultivo é uma prática que deve ser adotada para escolha de um melhor método para a regulação de populações de pragas. O objetivo deste trabalho foi determinar a ocorrência de parasitoides associados às larvas de Spodoptera frugiperda (J. E. Smith) (Lepidoptera: Noctuidae) e Dichomeris famulata Meyrick (Lepidoptera: Gelechiidae) na cultura do milho (Zea mays L.) em áreas de produção orgânica e convencional. O experimento foi conduzido no Centro Nacional de Pesquisa de Milho e Sorgo (CNPMS) em Sete Lagoas, Minas Gerais, Brasil, em área de produção orgânica e convencional. Hymenoptera parasitoides emergiram de $S$. frugiperda, incluindo Ichneumonidae: Campoletis flavicincta, Colpotrochia sp. nov., Eiphosoma laphygmae e Ophion flavidus; espécies de Braconidae: Chelonus (Chelonus) insularis, Dolichozele koebelei e Exasticolus sp. nov. Esse é o primeiro registro de Colpotrochia sp. nov., Dolichozele koebelei e Exasticolus sp. nov. parasitando S. frugiperda. De larvas de D. famulata, emergiram os Braconidae: Cotesia sp., Glyptapanteles sp., Phanerotoma sp. (Grupo Fuscovaria) e Chelonus (Microchelonus) sp. nov. (primeira ocorrência em D. famulata).

Palavras-chave: agroecologia, controle biológico, Braconidae, Ichneumonidae, taxonomia. 
The maize (Zea mays L.) production in Brazil can be explored throughout the year and their major use is for animal food. However, increase in demand for human consumption (industrial or fresh) bring to the farmers an alternative to increases income, especially when maize has any aggregated value to the final product such as the organic production (Figueiredo et al., 2005). In the conventional system, pest control is done by chemical insecticides that are effective for elimination of pests, but some are highly toxic to natural enemies, leading to their elimination from the ecosystem, favoring the occurrence of resistant populations and secondary pests, in addition to the disastrous consequences of these pesticides on the environment (Silva et al., 2011). Specifically for the fall armyworm Spodoptera frugiperda (J. E. Smith) (Lepidoptera: Noctuidae), the use of Bt maize has been effective and its utilization is increasing in Brazil, except in the area of refuge, where the conventional cultivars are used. Neither chemical insecticides nor Bt maize can be used to control pests in the organic system.

Organic production of maize in Brazil has shown a significant expansion every year and demand from consumers has received several countries legislation and incentives for their adoption. Such a system can benefit in particular small farmers who traditionally do not use the inputs available with the "green revolution". And in the case of maize, its importance is even greater, since it is a fundamental part of other segments of organic production such as meat, milk and eggs. Even in the production of single maize, organic production for direct human consumption as fresh maize or canned maize ("baby corn") can generate greater profitability for the producer (Figueiredo et al., 2009a).
Despite the expansion of planted area and the market demand, the research support has also contributed to the advancement of incipient organic production, which contributes to low productivity caused by biotic and abiotic stresses, along with inadequate management techniques, often form a barrier to the conversion of conventional systems for production of organic (Cruz et al., 2006).

In the context of the modern agriculture, pest control is important in order to increase maize productivity. However, this control should be done rationally, aiming to reduce pesticide use and should prioritize other more environmentally safe methods such as biological control, which enables the producer to reduce contamination of the product, the consumer and the environment. This method may offer lower costs and can use the richness of Brazilian fauna of the organisms with the potential to act as agents for pest control.

Many pests of maize are important in the agroecosystem and are well known, particularly in the conventional cultivation. The production of maize in the organic system still needs further research effort to determine the exact occurrence and economic importance of each pest species. Among these pests excel, S. frugiperda which occurs throughout most of the plant cycle (Cruz et al., 1999, 2009, 2010, 2012; Figueiredo et al., 2009b; Silva et al., 2010), and a new pest of the spike, whose incidence increased in recent years, Dichomeris famulata Meyrick (Lepidoptera: Gelechiidae) (Marques \& Nakano, 2009).

The knowledge of species and the flow of natural biological control agents in agricultural areas is essential to establish integrated management programs. Among the insects of interest for use in biological control highlights the group called parasitoids, due to its efficiency and specificity in relation to the host. 
The aim of this study was to determine the occurrence of parasitoids associated with $S$. frugiperda and D. famulata in maize in areas of organic and conventional production of the region of Sete Lagoas, Minas Gerais State, Brazil.

The experiment was conducted in the Cerrado region, at fields and in the Lacri (Insect Rearing Laboratory) of the CNPMS (National Research Center for Maize and Sorghum) in Sete Lagoas,

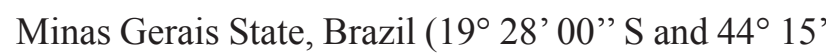
$00 " \mathrm{~W})$.

In the 2010/2011 season, two areas of approximately one hectare each, called organic farming and conventional farming area, isolated from each other by a distance greater than 3000 meters, were cultivated with maize variety BR 106, without application of chemical insecticides.

In order to determine the initial appearing and frequency of fall armyworm moths during the experiment, shortly after emergence of maize plants, a delta trap (Ferocon $1 \mathrm{C}^{\circledR}$ )was installed in the center of each experimental area, containing the synthetic sex pheromone of $S$. frugiperda, BIO SPODOPTERA ${ }^{\circledR}$ (Chem Tica International, SA) type sachet (Cruz et al., 2010, 2012).

In each planting area, 24 plots of equal size were established. As soon as the trap detected the first $S$. frugiperda moths, samples were taken in each plot. Three times a week, during all plant vegetative stage, 10 plants per plot were harvested and evaluated in Lacri (climatized rooms at $25 \pm 2{ }^{\circ} \mathrm{C}$, RH $70 \pm$ $10 \%$ and photophase of 12 hours), separating the larvae by species and placing them individually in plastic cups containing artificial diet (Cruz, 2009) where they remained until the end of the life cycle. For each parasitoid emerged it was recorded the host development stage in which it emerged. After tasselling the samples were also taken from ear, three times a week. All procedure was similar to the plant samples.

The parasitoids emerged from $S$. frugiperda and $D$. famulata were identified by five of the authors (M.A.B., A.G.P., I.F.M., L.F.C. and A.M.P.D.).

From the collected larvae of $S$. frugiperda emerged the Hymenoptera, Ichneumonidae Campoletis flavicincta (Ashmead), Colpotrochia sp. nov., Eiphosoma laphygmae Costa Lima, Ophion flavidus Brullé and the Braconidae Chelonus (Chelonus) insularis Cresson, Dolichozele koebelei Viereck and Exasticolus sp. nov. Dolichozele koebelei, Colpotrochia sp. nov. and Exasticolus sp. nov. are registered for the first time associated with $S$. frugiperda and the latter two species are new ones.

From D. famulata emerged the Braconidae Cotesia sp., Glyptapanteles sp., Phanerotoma sp. (Fuscovaria group) and Chelonus (Microchelonus) sp. nov. (first occurrence in D. famulata).

The results indicate the potential of the parasitoids as natural biological control agents for use in integrated management programs of phytophagous insects in maize. In addition to the species reported in the literature (Figueiredo et al., 2006; Penteado-Dias et al., 2006; Cruz, 2008), new species were found and are being evaluated in the laboratory to determine important biological aspects such as life cycle, potential as biological control agents and feasibility of mass rearing.

\section{Acknowledgements}

To "Coordenação de Aperfeiçoamento de Pessoal de Nível Superior (Capes)", "Conselho 
Nacional de Desenvolvimento Científico e Tecnológico (CNPq)", "Fundação de Amparo à Pesquisa do Estado de Minas Gerais (Fapemig)", "Fundação de Amparo à Pesquisa do Estado de São Paulo (Fapesp)" and "Instituto Nacional de Ciência e Tecnologia dos Hymenoptera Parasitóides da Região Sudeste Brasileira (INCT/Hympar-Sudeste)" for financial support.

\section{References}

CRUZ, I.; FIGUEIREDO, M. L. C.; OLIVEIRA, A. C.; VASCONCELOS, C. A. Damage of Spodoptera frugiperda (Smith) in different maize genotypes cultivated in soil under three levels of aluminium saturation. International Journal of Pest Management, London, v. 45, n. 1, p. 293-296, 1999.

CRUZ, I. (Ed.). Manual de identificação de pragas do milho e de seus principais agentes de controle biológico. Brasília, DF: Embrapa Informação Tecnológica, 2008. 166 p.

CRUZ, I. Métodos de criação de agentes entomófagos de Spodoptera frugiperda (J. E. Smith). In: BUENO, V. H. P. (Ed.). Controle biológico de pragas: produção massal e controle de qualidade. Lavras: UFLA, 2009a. p. 111-135.

CRUZ, I.; FIGUEIREDO, M. L. C.; SILVA, R. B.; DEL SARTO, M. C. L.; PENTEADO-DIAS, A. M. Monitoramento de parasitoides de lagartas de Spodoptera frugiperda (J. E. Smith) (Lepidoptera: Noctuidae) em municípios de Minas Gerais, Brasil. Sete Lagoas: Embrapa Milho e Sorgo, 2009b. 29 p. (Embrapa Milho e Sorgo. Documentos, 92).

CRUZ, I.; FIGUEIREDO, M. L. C.; SILVA, R. B.; FOSTER, J. E. Efficiency of chemical pesticides to control Spodoptera frugiperda and validation of pheromone trap as a pest management tool in maize crop. Revista Brasileira de Milho e Sorgo, Sete Lagoas, v. 9, n. 2, p. $20-27,2010$.

CRUZ, I.; FIGUEIREDO, M. L. C.; SILVA, R.B.; SILVA, I. F.; PAULA, C. S.; FOSTER, J. E. Using sex pheromone traps in the decision-making process for pesticide application against fall armyworm (Spodoptera frugiperda [Smith] [Lepidoptera: Noctuidae]) larvae in maize. International Journal of Pest Management, London, v. 58, p. 83-90, 2012.

CRUZ, J. C.; KONZEN, E. A.; PEREIRA FILHO, I. A.; MARRIEL, I. E.; CRUZ, I.; DUARTE, J. O.; OLIVEIRA, M. F.; ALVARENGA, R. C. Produção de milho orgânico na agricultura familiar. Sete Lagoas: Embrapa Milho e Sorgo, 2006. 17 p. (Embrapa Milho e Sorgo. Circular Técnica 81). Disponível em: $<$ http:// www.cnpms.embrapa.br/publicacoes/publica/2006/ circular/Circ_81.pdf $>$ Acesso em: 20 nov. 2011.

FIGUEIREDO, M. L. C.; PENTEADO-DIAS, A. M. P.; CRUZ, I. Efeito do inseticida Match e sua interação com os inimigos naturais no controle de Spodoptera frugiperda (Smith, 1797), na cultura do milho. Sete Lagoas: Embrapa Milho e Sorgo, 2005. 6 p. (Embrapa Milho e Sorgo. Comunicado Técnico, 131). Disponível em: $\quad<$ http://www.cnpms.embrapa.br/publicacoes/ publica/2005/comunicado/Com_131.pdf $>$ Acesso em: 10 out. 2011.

FIGUEIREDO, M. L. C.; MARTINS-DIAS, A. M. P.; CRUZ, I. Exasticolus fuscicornis em lagartas de Spodoptera frugiperda. Pesquisa Agropecuária Brasileira, Brasília, DF, v. 41, p. 1321-1323, 2006.

FIGUEIREDO, M. L. C.; CRUZ, I.; PENTEADO-DIAS, A. M.; SILVA, R. B. Ocorrência do parasitóide Chelonus insularis no Sul de Minas Gerais associado a lagartas de Spodoptera frugiperda na cultura de milho. Revista Brasileira de Agroecologia, Curitiba, v. 4, p. 4281- 
4284, 2009a.

FIGUEIREDO, M. L. C.; CRUZ, I.; PENTEADO-DIAS,

A. M.; SILVA, R. B. interaction between Baculovirus spodoptera and natural enemies on the suppression of Spodoptera frugiperda (J. E. Smith) (Lepidoptera: Noctuidae) in maize. Revista Brasileira de Milho e Sorgo, Sete Lagoas, v. 8, n. 3, p. 207-222, 2009 b.

MARQUES, L. H.; NAKANO, O. Futuro ameaçado. Revista Cultivar - Grandes Culturas, Pelotas, v. 11, n. 22, p. 6, 2009.

PENTEADO-DIAS, A. M. P.; FIGUEIREDO, M. L. C.; MARTINS-DIAS, M.; OSÓRIO, T. C.; CRUZ, I. First host records for Exasticolus fuscicornis (Cameron, 1887) (Hymenoptera: Braconidae: Homolobinae).
Zoölogische Mededelingen, Leiden, v. 80, n. 1, p. 109-112, 2006.

SILVA, R. B.; CRUZ, I.; FIGUEIREDO, M. L. C.; SOUZA, W. T. Development of Coleomegilla maculata De Geer (Coleoptera: Coccinellidae) with prey and artificial diet. Revista Brasileira de Milho e Sorgo, Sete Lagoas, v. 9, n. 1, p. 13-26, 2010.

SILVA, R. B.; CRUZ, I.; FIGUEIREDO, M. L. C.; COSTA, M. A.; REDOAN, A. C.; MORATO, J. B. Dinâmica populacional de parasitoides de Spodoptera frugiperda (J. E. Smith) (Lepidoptera: Noctuidae) em milho (Zea mays L.) cultivado no sistema orgânico de produção. Cadernos de Agroecologia, Fortaleza, v. 6, p. 1-5, 2011. 